\title{
Numerical modeling of gravity-driven sediment transport and deposition on an energetic continental shelf: Eel River, northern California
}

\author{
M. Scully \\ Virginia Institute of Marine Science \\ Carl T. Friedrichs \\ Virginia Institute of Marine Science, carl.friedrichs@vims.edu \\ L. D. Wright \\ Virginia Institute of Marine Science
}

Follow this and additional works at: https://scholarworks.wm.edu/vimsarticles

Part of the Marine Biology Commons

\section{Recommended Citation}

Scully, M.; Friedrichs, Carl T.; and Wright, L. D., "Numerical modeling of gravity-driven sediment transport and deposition on an energetic continental shelf: Eel River, northern California" (2003). VIMS Articles. 281. https://scholarworks.wm.edu/vimsarticles/281 


\title{
Numerical modeling of gravity-driven sediment transport and deposition on an energetic continental shelf: Eel River, northern California
}

\author{
M. E. Scully, C. T. Friedrichs, and L. D. Wright \\ Virginia Institute of Marine Science, College of William and Mary, Gloucester Point, Virginia, USA \\ Received 10 May 2002; revised 4 December 2002; accepted 22 January 2003; published 16 April 2003.
}

[1] A two-dimensional numerical model was applied to predict large-scale deposition by wave-supported sediment gravity flows on the Eel River continental shelf for four consecutive flood seasons using measured bathymetry, waves and river forcing. The model assumes that sediment-induced stratification maintains the near-bed Richardson number at its critical value, which determines the sediment carrying capacity of the wave boundary layer. Deposition is predicted when the gravity-driven flux of sediment exceeds the carrying capacity. The model predicted $26 \%$ of fine sediment discharged by the Eel River to be deposited on the midshelf with a magnitude and distribution largely consistent with field observations. Greatest deposition on the midshelf was predicted well north of the river mouth despite greater sediment input nearest the river mouth. Model results indicate that when the river delivers sufficient sediment to critically stratify the wave boundary layer, wave intensity and the bathymetry of the Eel shelf are the dominant factors controlling the observed pattern of deposition. Large wave energy caused the majority of fine sediment (65\%) to escape the shelf as gravity-driven flows. The greatest amount of sediment was predicted to leave the shelf from the region off-shelf of the river mouth (including 11\% into the Eel Canyon) where inshore sediment input was high and the concave downward bathymetry associated with the Eel River subaqueous delta prevents significant midshelf gravity-driven deposition. INDEX TERMS: 4219 Oceanography: General: Continental shelf processes; 3022 Marine Geology and Geophysics: Marine sediments-processes and transport; 4558 Oceanography: Physical: Sediment transport; 4259 Oceanography: General: Ocean acoustics; 4568 Oceanography: Physical: Turbulence, diffusion, and mixing processes; KEYWORDS: fluid mud, wave-supported gravity flows, critical Richardson number, STRATAFORM, Eel River continental margin

Citation: Scully, M. E., C. T. Friedrichs, and L. D. Wright, Numerical modeling of gravity-driven sediment transport and deposition on an energetic continental shelf: Eel River, northern California, J. Geophys. Res., 108(C4), 3120, doi:10.1029/2002JC001467, 2003.

\section{Introduction}

[2] The Eel River drains a relatively small $\left(9500 \mathrm{~km}^{2}\right)$ basin in the northern California Coastal Range. It has the largest annual yield of any river of comparable or larger basin-size in the conterminous United States [Brown and Ritter, 1971]. Its discharge is episodic on both inter- and intra-annual timescales, with nearly all of the discharge occurring in association with large winter storms. The physical and geological processes controlling sedimentation on the Eel River continental margin have been studied extensively during the Office of Naval Research STRATAFORM program [Nittrouer, 1999]. Numerous cores collected from the continental shelf adjacent to the Eel River reveal that following significant floods, fine-grained sediment accumulates in a distinct flood deposit centered near the 70-m isobath and extends over $30 \mathrm{~km}$ along shelf and

Copyright 2003 by the American Geophysical Union. 0148-0227/03/2002JC001467
$8 \mathrm{~km}$ across shelf [Wheatcroft et al., 1997; Borgeld et al., 1999; Drake, 1999; Sommerfield and Nittrouer, 1999; and Wheatcroft and Borgeld, 2000] (Figure 1). Distinct finegrained flood deposits from both the winter of 1994-1995 and 1996-1997 appear in cores, while no significant deposits from the 1995-1996 and 1997-1998 seasons were preserved [Wheatcroft et al., 1997; Borgeld et al., 1999; Drake, 1999; Sommerfield and Nittrouer, 1999; Wheatcroft and Borgeld, 2000; Drake et al., 2000].

[3] Samples collected by helicopter surveys indicate that during the winter floods of 1996-1997 and 1997-98, the Eel River plume exited the river mouth and traveled north, staying inshore of the 40-m isobath [Geyer et al., 2000]. Estimates suggest that 40 to $75 \%$ of the sediment discharged by the Eel River settles out of the plume before reaching the K-transect (Figure 1), mainly as flocculated aggregates [Geyer et al., 2000; Hill et al., 2000]. While the majority of river sediment is thought to settle out of the plume inshore of the 40-m isobath, observations collected from instrumented tripods located on the $60-\mathrm{m}$ isobath indicate that 


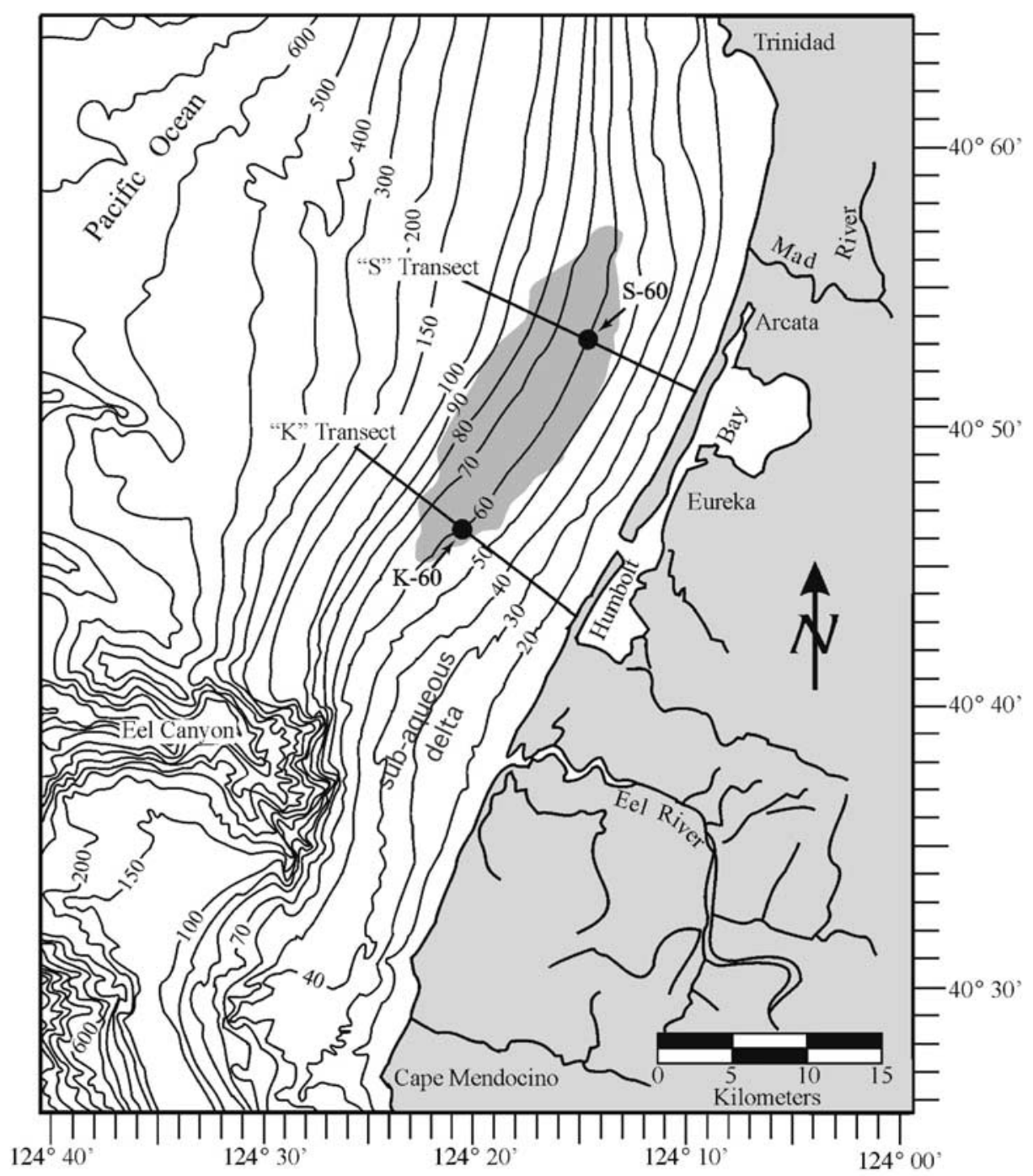

Figure 1. Site map of the STRATAFORM study area including the locations of tripod deployments and general location of the 1995 and 1997 flood deposits (shaded area) based on Wheatcroft et al. [1997] and Wheatcroft and Borgeld [2000].

following floods of the Eel River, down-slope gravity-driven transport of thin fluid mud layers accounts for the majority of the observed sediment flux and deposition at the midshelf [Ogston et al., 2000; Traykovski et al., 2000]. The analytical modeling of Scully et al. [2002] further demonstrates that tripod-based time series observations and large-scale corebased patterns of observed deposition on the midshelf of the Eel margin are consistent with gravity-driven processes.

[4] Gravity-driven processes play a key role in the formation of the midshelf flood deposit on the Eel Shelf. However, estimates based on cores indicate that less than $25 \%$ of the sediment discharged by the Eel River during the January 1995 flood can be accounted for in the flood deposit [Wheatcroft et al., 1997]. In fact, the ultimate fate of sediment discharged by the Eel River still remains poorly understood. It has been proposed that the majority of the missing sediment is widely dispersed by the highly energetic oceanic conditions that occur during winter floods of the Eel River [Wheatcroft et al., 1997]. However, recent investigations indicate that Eel Canyon is an active off-shelf sink for river-derived sediment [Mullenbach and Nittrouer, 2000]. Additionally, there is evidence that significant amounts of fine-grained sediment may be sequestered and stored among the inner-shelf sand deposits (J.S. Crockett and C.A. Nittrouer, The anatomy of a sandy inner shelf: An example from northern California, submitted to Continental Shelf Research, 2002) (hereinafter referred to as Crockett and Nittrouer, submitted manuscript, 2002). Analytical modeling suggests that significant quantities of sediment from the Eel River may enter Eel Canyon or escape past the shelf break as gravity-driven flows [Scully et al., 2002]. Scully et al. [2002] also indicate that following large floods of the Eel River with low associated wave energy, gravitydriven processes are not capable of removing all the sediment delivered to the inner shelf and significant inner-shelf deposition is possible.

[5] Accurately representing gravity-driven processes will be crucial to successfully modeling sediment transport and deposition on energetic continental shelves with high sediment input such as the Eel margin. The high concentrations 
of suspended sediment necessary to initiate gravity-driven flows make it an extremely effective mechanism for transporting sediment. While there have been modeling efforts that focus on gravity-driven turbidity currents on the continental slope [Komar, 1977; Parker et al., 1986], little effort has been made to model gravity-driven processes on the continental shelf that are not associated with the direct discharge of a negatively buoyant hyperpycnal plume [Mulder and Syvitski, 1995; Mulder et al., 1998]. Gravitydriven transport on the continental shelf is fundamentally different from the processes acting on the continental slope. Turbidity currents on the continental slope are usually initiated by sediment failure and sediment is maintained in suspension by internally generated turbulence associated with the flow, enabling them to propagate down-slope [Parker et al., 1986]. On the continental shelf, bed slopes are generally too mild to allow auto-suspending gravitydriven transport [Wright et al., 2001] and gravity-driven transport requires an external source of turbulence to propagate down-slope [Traykovski et al., 2000]. Wright et al. [2001] developed an analytical model to predict downslope gravity-driven transport and deposition that includes turbulence generated by waves and ambient currents.

[6] In this paper, we use the analytical formulation of Wright et al. [2001] to develop a two-dimensional numerical model for the Eel shelf. The model is intended to realistically represent the first-order forcings in order to predict large-scale deposition of fine-grained sediment on the continental shelf following floods of the Eel River. Application of the model is intended to build upon the work of Scully et al. [2002] by predicting deposition over a large area using realistic shelf bathymetry in a manner that is computationally efficient. By accounting only for gravitydriven transport and deposition, the model is relatively simple and allows us to focus on the importance of this mechanism. The numerical approach allows us to examine more thoroughly the role that gravity-driven processes play in the fate of flood-derived fine sediment, further constraining the overall sediment budget for the Eel River system. Sensitivity analysis highlights the importance of processes that influence gravity-driven transport and deposition, and provides further insight into the formation and preservation of flood deposition on the Eel margin.

\section{Model}

\subsection{Theoretical Development}

[7] The model applies the linearized form of the Chezy equation presented by Wright et al. [2001] for gravitydriven flows trapped within the wave boundary layer,

$$
\alpha \mathrm{B} \approx \mathrm{C}_{\mathrm{d}} \mathrm{u}_{\max } \mathrm{u}_{\text {grav }},
$$

where $\alpha$ is the sine of the bottom slope, $C_{d}$ is the bottom frictional drag coefficient, $u_{\max }$ is the magnitude of the velocity scale at the top of the wave boundary layer, $u_{\text {grav }}$ is the down-slope gravity current speed, and B is the depth integrated negative buoyancy anomaly defined as

$$
\mathrm{B}=\mathrm{gs} \int_{0}^{\delta} c^{\prime} \partial \mathrm{z}
$$

In equation (2), $\mathrm{g}$ is the acceleration of gravity, $\mathrm{s}$ is the submerged weight of siliceous sediment relative to seawater, $\delta$ is the layer thickness, and $c^{\prime}$ is the sediment volume concentration. Following the formulation of Wright et al. [2001], the value of $u_{\max }$ includes contributions from the wave orbital velocity amplitude $\left(u_{\text {wave }}\right)$, the along-shelf current magnitude $\left(\mathrm{v}_{\text {curr }}\right)$, and the down-slope gravity current speed $\left(\mathrm{u}_{\text {grav }}\right)$ and is given as

$$
u_{\max }=\sqrt{u_{\text {wave }}^{2}+v_{\text {curr }}^{2}+u_{\text {grav }}^{2}} .
$$

[8] Consistent with observations made in the current boundary layer on the Eel River continental shelf [Wright et al., 1999], as well as sediment laden tidal boundary layers on the Amazon shelf [Trowbridge and Kineke, 1994], the model assumes that following large floods of the Eel River a negative feedback maintains the gradient Richardson number $\left(\mathrm{Ri}_{\mathrm{g}}\right)$ of the wave boundary layer near its critical value [Wright et al., 2001]. Following the scaling argument of Trowbridge and Kineke [1994] for a tidal boundary layer, $\mathrm{Ri}_{\mathrm{g}}$ can be represented simply as the ratio of the buoyancy anomaly to the shear produced by the maximum velocity scale, or

$$
\mathrm{Ri}_{\mathrm{g}}=\frac{\mathrm{B}}{\mathrm{u}_{\max }^{2}}
$$

[9] For tidal boundary layers on the continental shelf off the Amazon River, Trowbridge and Kineke [1994] found that vertical transport was controlled by the suppression of turbulent mixing when $\mathrm{Ri}_{\mathrm{g}}$ was maintained near its critical value of 0.25 due to the presence of high concentration fluid mud layers. They presented a one-dimensional model that assumed that $\mathrm{Ri}_{\mathrm{g}}$ was maintained at its critical value everywhere within the boundary layer. Although their solution is unrealistic at the very top and bottom of the boundary layer, their results suggest that the structure in the majority of the flow is controlled by the suppression of turbulent mixing and $\mathrm{Ri}_{\mathrm{g}} \sim 0.25$. Building upon these results, we assume that following floods of the Eel River, sufficient easily suspended sediment is available so that a negative feedback mechanism maintains $\mathrm{Ri}_{\mathrm{g}}$ for the wave boundary layer at its critical value $\left(\mathrm{Ri}_{\mathrm{cr}}=0.25\right)$. Our scaling is analogous to the classical bulk Richardson number $\left(\mathrm{Ri}_{\mathrm{b}}\right)$ because we do not attempt to resolve the velocity profile within the wave boundary layer. If one assumes that the velocity profile within the wave boundary layer is approximately linear at lowest order, our scaling is equivalent to $\mathrm{Ri}_{\mathrm{b}}=1$, because the bulk scaling of the velocity shear is classically represented by the average velocity. This is consistent with the findings of Kundu [1981], who showed that a boundary layer with a critical $\mathrm{Ri}_{\mathrm{b}}$ is consistent with the maintenance of $\mathrm{Ri}_{\mathrm{g}}$ at its critical value throughout the layer. Interpretation of laboratory experiments indicates that $\mathrm{Ri}_{\mathrm{b}}$ often maintains a relatively constant value of unity for turbulent flows with stable stratification [Price, 1979; Thompson, 1979].

[10] If one assumes that $\mathrm{Ri}_{\mathrm{g}}$ is maintained at its critical value $\left(\mathrm{Ri}_{\mathrm{cr}}=0.25\right)$, the approximate capacity of the boundary layer to hold sediment can be calculated from equation (4) by only knowing the appropriate near-bed velocity scale. On the Eel River continental shelf, it is reasonable to 
assume that wave orbital velocities will dominate the nearbed velocity scale. However, the gravity-driven velocity also will make a significant contribution at times when high concentrations of suspended sediment are present. Scully et al. [2002] re-expressed $\mathrm{u}_{\max }$ for periods when the boundary layer is carrying its maximum capacity as

$$
\mathrm{u}_{\max }=\sqrt{\frac{\mathrm{u}_{\mathrm{wave}}^{2}+\mathrm{v}_{\mathrm{curr}}^{2}}{1-\beta^{2}}},
$$

where

$$
\beta=\frac{\alpha \mathrm{Ri}_{\mathrm{cr}}}{\mathrm{C}_{\mathrm{d}}}
$$

[11] Wave orbital velocity at a given depth can be reasonably inferred from observations of surface wave height and period for a general area. If the relatively minor influence of the along-shelf current is ignored, the carrying capacity of the wave boundary layer for a large region of the shelf can be calculated knowing only the relevant surface wave height and period. The model is based upon the relatively simple idea that deposition occurs when the sediment carrying capacity of the wave boundary layer, given by equating (4) to the critical value of 0.25 , is exceeded.

\subsection{Model Implementation}

[12] The model domain in our application of the above equations consists of a 72 by 64 rectangular element grid rotated to conform to the dominant along-shelf direction. Each point in the grid represents an area $1000 \mathrm{~m}$ in the along-shelf direction and $400 \mathrm{~m}$ in the across-shelf direction. The grid covers roughly the region from $10 \mathrm{~km}$ south of the river mouth to approximately $50 \mathrm{~km}$ north of the river mouth from the coastline to out beyond the 200-m isobath. The bathymetry for the model was obtained by fitting a fourth-order polynomial to across-shelf transects of N.O.S. bathymetry data followed by along-shelf smoothing using a third-order polynomial and interpolating to obtain the depth and slope for each grid point. Bathymetry must be smoothed somewhat because frictionally dominated gravity flows will otherwise pool unrealistically behind small irregularities in bathymetry.

[13] Wave orbital velocities are calculated for each point in the model grid based on an interpolation of hourly observations of wave energy density made at NDBC buoy 46022 , located offshore and slightly north of the Eel River mouth. Following the methods of Sherwood et al. [1994], the bottom orbital velocity for each model grid point is calculated from the energy density spectrum knowing the local depth and accounting for the frequency-based decay. Comparison of this method with observations of near-bed velocity collected at various tripods shows good agreement, but with a slight overprediction. To correct for this overprediction, a coefficient of 0.79 is applied to the predicted velocity, consistent with the mean ratio between tripod observations and the prediction based on the work of Sherwood et al. [1994]. On the Eel River continental shelf, it is reasonable to assume that wave orbital velocities during storms dominate the near-bed velocity scale relative to the

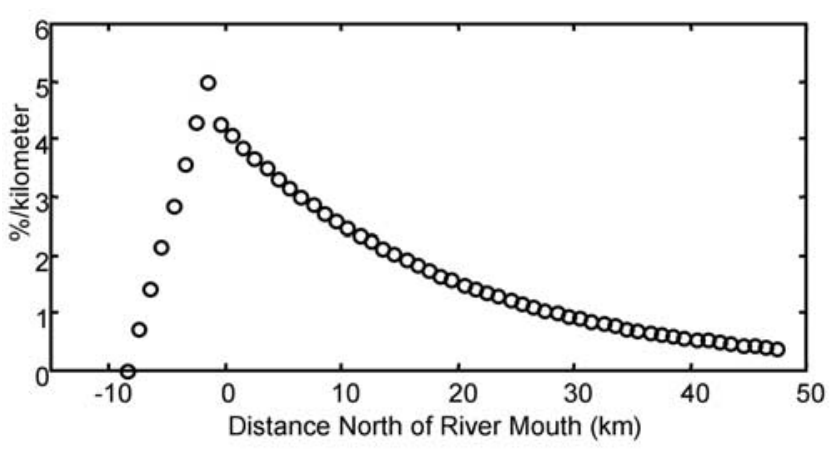

Figure 2. Modeled along-shelf sediment distribution with exponentially decaying sediment delivery north of the river mouth (e-folding length $=20 \mathrm{~km}$ ).

along-shelf current. However, the gravity-driven velocity also will make a significant contribution at times when high concentrations of suspended sediment are present. Therefore, the near-bed velocity scale that governs the capacity of the boundary layer to hold sediment is calculated using equation (5), to include the influence of $u_{\text {grav }}$ on $u_{\max }$. If the relatively minor influence of the along-shelf current is ignored, the carrying capacity of the wave boundary layer for a large region of the shelf can be calculated knowing only the relevant surface wave height and period.

[14] Fine-grained sediment input is calculated by applying the rating curve of Syvitski and Morehead [1999] to the discharge data from the USGS gauging stations at Scotia on the main stem of the Eel River and at the Bridgeville station on the van Duzen River. The discharge at Bridgeville is doubled and added to the discharge at Scotia to account for inputs downstream of the Scotia gauging station, and an upper limit on suspended sediment concentration within the river of $7 \mathrm{~g} / \mathrm{L}$ is established consistent with the methods of Wheatcroft et al. [1997]. The predicted sediment load is reduced by $25 \%$ to remove the estimated percentage of sand [Brown and Ritter, 1971; Geyer et al., 2000]. The remaining sediment represents our best estimate of fine-grained sediment input to the ocean. Only fine-grained river sediment that is input during floods is transported and deposited by the model. Neither coarse-grained sediment nor pre-existing shelf sediment is accounted for in the model.

[15] Using a 30-min time step, the calculated sediment load is spread along the coast north of the river mouth to create an inshore deposit. The inshore deposit is defined as covering the region extending from $8.5 \mathrm{~km}$ south of the river mouth to $50 \mathrm{~km}$ north of the river mouth and between the 15 $\mathrm{m}$ and $35-\mathrm{m}$ isobaths. The along-shelf distribution of river sediment is determined by spreading $80 \%$ of the fine-grain sediment discharged along the coast to the north of the river mouth with an e-folding length of $20 \mathrm{~km}$ with the remaining $20 \%$ of the sediment spread over the $8.5-\mathrm{km}$ region south of the river mouth with a linear decrease (Figure 2). The alongshelf delivery of sediment is consistent with the results reported by Geyer et al. [2000], as well as observations of temporary and significant inshore deposition of flood derived sediment reported by Traykovski et al. [2000]. The region inshore of the $15-\mathrm{m}$ isobath was neglected in an attempt to avoid the complicated dynamics associated with the surf-zone during high-energy river floods. 
[16] The inshore deposit is used as the source of sediment for gravity-driven transport. With each time step, sediment is added to the inshore deposit where it is resuspended into the wave boundary layer when a resuspension threshold is exceeded. The down-slope flux of suspended sediment in the boundary layer is calculated knowing the integrated buoyancy and iteratively solving equations (1) and (3) for the gravity-driven velocity. When the boundary layer is carrying its maximum capacity, the solution to equations (3) and (5) converge. For many grid points, the bed slope consists of both an across-shelf and along-shelf component. For each grid point, the gravity-driven flux is partitioned into an across-shelf and along-shelf component based on the relative strength of the bed slope. Deposition is predicted when flux convergence causes the capacity of the wave boundary layer, as given by equating (4) to the critical value of 0.25 , to be exceeded. Both erosion and deposition are governed by the capacity of the wave boundary layer. For any given time step, the amount of erosion or deposition in units of $\mathrm{kg} / \mathrm{m}^{2}$ can be represented as

$$
\text { Deposition or Erosion }=\frac{\rho_{\mathrm{sed}}}{\mathrm{g} \mathrm{s}}\left[\mathrm{B}-\left(\mathrm{u}_{\mathrm{max}}^{2} \mathrm{Ri}_{\mathrm{cr}}\right)\right] \text {, }
$$

where $\rho_{\text {sed }}$ is the density of siliceous sediment. Positive values indicate deposition and negative values indicate erosion. Thus, erosion can only occur when the wave boundary layer is not carrying its maximum load. Erosion of deposited sediment is only predicted to occur when the calculated orbital velocity exceeds an established threshold value $(0.35 \mathrm{~m} / \mathrm{s}$ for the base model run). Both deposition and erosion are assumed to occur rapidly enough to bring the amount of suspended sediment in the wave boundary layer to the maximum capacity in one time step. If sufficient sediment is not available to meet the capacity of the wave boundary layer and the critical resuspension criteria is exceeded, only the available sediment in the bed is resuspended.

[17] Consistent with the results of Wright et al. [2001], the value of $C_{d}$ in equation (1) varies inversely with Ri. Ri is calculated following equation (4), knowing the integrated buoyancy anomaly (B) and $\mathrm{u}_{\max }$ at all points within the model domain. The drag coefficient is then calculated from the following linear relationship based on the results of Wright et $a l$. [2001] for both the wave and current boundary layer,

$$
\mathrm{C}_{\mathrm{d}}=0.01-(0.028 \mathrm{Ri})
$$

This relationship establishes a lower limit on $\mathrm{C}_{\mathrm{d}}$ of 0.003 for critically-stratified conditions and an upper limit of 0.01 when sediment-induced stratification is absent. Higher $C_{d}$ in combination with lower concentrations of suspended sediment effectively limit gravity-driven sediment transport when critical stratification is absent. However, the model assumes some gravity-driven transport occurs whenever there is sediment suspended in the boundary layer.

[18] Using this relatively simple approach, we simulated gravity-driven sediment transport and deposition. The model's base run was designed to account only for transport and deposition by gravity-driven processes. While the ambient currents will play some role, they are not accounted for in the model. However, the observations of Traykovski et al.
[2000] and the results of Scully et al. [2002] give us confidence that when density-driven processes are active, they represent the dominant mode of sediment transport. The model only accounts for fine sediment and does not include coarser grained material whose transport may be governed by other mechanisms.

\section{Results}

[19] The model was run for four consecutive flood seasons beginning in 1994-1995. These four winter seasons represent a wide range of observed river discharge and wave energy. The time period for the model runs was selected to encompass the significant river discharge events for each year. Figure 3 shows the estimated river discharge and bottom wave orbital velocity calculated at the $60 \mathrm{~m}$ depth for the four periods of time to which the model was applied. The predicted fate of fine sediment for the various model runs is shown in Table 1. The distribution of predicted shelf deposition is shown in Figure 4. The predicted flood deposit thickness was calculated assuming a porosity of 0.75 , consistent with the partially dewatered flood layers observed in cores by Wheatcroft and Borgeld [2000].

\subsection{Midshelf Deposition}

[20] Significant midshelf deposition was predicted during the 1994-1995 and 1996-1997 periods when historically large floods of the Eel River occurred. The model predicts that roughly $29 \%$ and $39 \%$ of the fine sediment discharged from the Eel River was deposited on the midshelf (between $50 \mathrm{~m}$ and the shelf break) during 1994-1995 and 19961997, respectively, and $26 \%$ over all four flood seasons together (Table 1). These results agree favorably with estimates extrapolated from core data that indicate approximately $25 \%$ of the fine sediment was preserved in the flood deposit following the January flood of 1995 [Wheatcroft et al., 1997] and that about $20 \%$ of the Eel River fine sediment discharge over the last 100 years has been preserved on the shelf [Sommerfield and Nittrouer, 1999]. The thickness of predicted midshelf deposition of river-derived fine sediment also is consistent with the thickness observed in midshelf cores. Wheatcroft and Borgeld [2000] report maximum midshelf flood layer thickness of 8,5 , and $5 \mathrm{~cm}$ along the 70-m isobath for the January 1995, March 1995, and January 1997 floods, respectively. This agrees favorably with our model results that indicate maximum deposition along the 70-m isobath of $11.7 \mathrm{~cm}$ for the combined floods of 1995 and $3.4 \mathrm{~cm}$ following the 1997 flood season. Although the model slightly underpredicts deposition along the 70-m isobath during 1996-1997, greater deposition was predicted along the $60-\mathrm{m}$ isobath with a maximum thickness of over $8 \mathrm{~cm}$.

[21] No significant flood layers associated with the 1995-1996 and 1997-1998 flood seasons were observed in cores collected from the midshelf [Wheatcroft and Borgeld, 2000; Drake et al., 2000]. The model predicted $16 \%$ and $3 \%$ of the sediment discharge remaining on the midshelf during 1995-1996 and 1997-1998, respectively. Maximum predicted deposition at $70 \mathrm{~m}$ was less than $1 \mathrm{~cm}$ for 1997-1998. Although maximum deposition along the 70-m isobath in 1995-1996 was predicted to be $3.9 \mathrm{~cm}$, significant deposition was not widespread. In fact, total 

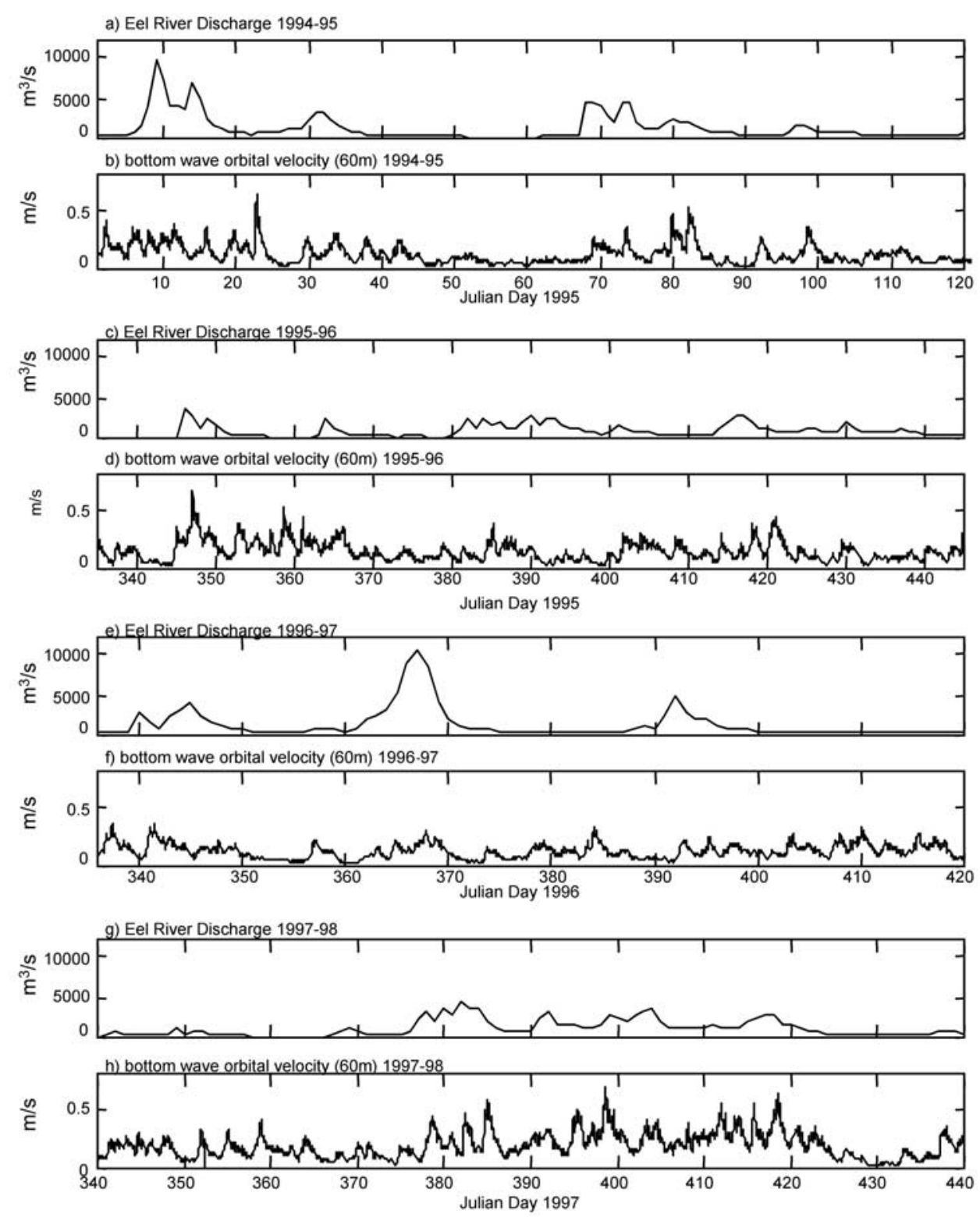

Figure 3. River discharge measured at Scotia and Bridgeville gauging stations and bottom wave energy calculated at $60-\mathrm{m}$ depth from NDBC buoy 46022 spectral wave energy density for the four periods to which the model was applied.

midshelf deposition was predicted to be more than 6 times greater in 1996-1997. Although the predicted midshelf deposition during 1995-1996 and 1997-1998 was substantially less than 1994-1995 and 1996-1997, there exists observational evidence for gravity-driven transport at the midshelf during these years. Wright et al. [2001] provide evidence for weak gravity-driven transport at the 60-m isobath on the S-transect (S-60) during 1995-1996, and Traykovski et al. [2000] observed significant local gravitydriven deposition at $60 \mathrm{~m}$ on the K-transect (K-60) during 1997-1998. The analytic results of Scully et al. [2002] demonstrated an ability to reproduce the timing and magnitude of the observed deposition at K-60, assuming that sufficient sediment was supplied to critically stratify the wave boundary layer. However, their results also suggested that during the 1997-1998 flood season, gravity-driven deposition may have only occurred over a very limited region of the shelf near the K-transect. The 2-D numerical modeling was unable to reproduce the magnitude of observed deposition at K-60 without significantly increasing the predicted sediment delivery to this area. This suggests that in 1997-1998, gravity-driven deposition may have only occurred over a relatively small region of the shelf, where delivery of sediment from the plume was locally enhanced in a manner not captured by the simple along-shelf distribution of sediment in Figure 2.

[22] An examination of the time series of predicted deposition supports the analytical modeling results of Scully et al. [2002] that suggest that the magnitude of wave energy plays a crucial role in controlling midshelf gravity-driven 
Table 1. Predicted Fate of Gravity-Driven Sediment Transport for Various Model Runs

\begin{tabular}{|c|c|c|c|c|c|c|c|}
\hline \multirow[b]{2}{*}{ Year } & \multirow[b]{2}{*}{$\begin{array}{l}\text { Sediment Input } \\
\left(10^{10} \mathrm{~kg}\right)\end{array}$} & \multirow[b]{2}{*}{$\begin{array}{l}\text { Inner-Shelf } \\
\text { Deposition }\end{array}$} & \multirow[b]{2}{*}{$\begin{array}{c}\text { Midshelf } \\
\text { Deposition }\end{array}$} & \multirow[b]{2}{*}{$\begin{array}{c}\text { Canyon } \\
\text { Flux }\end{array}$} & \multirow[b]{2}{*}{$\begin{array}{l}\text { Off-Shelf } \\
\text { Flux }\end{array}$} & \multicolumn{2}{|c|}{ Max. Deposition (at $70 \mathrm{~m}$ ) } \\
\hline & & & & & & $\begin{array}{c}\text { Thickness, } \\
\mathrm{cm}\end{array}$ & $\begin{array}{c}\text { Distance From } \\
\text { River Mouth, km }\end{array}$ \\
\hline \multicolumn{8}{|c|}{ Base Model Run } \\
\hline $1994-1995$ & 3.12 & $<1 \%$ & $29 \%$ & $11 \%$ & $59 \%$ & 11.7 & 26.5 \\
\hline $1995-1996$ & 0.95 & $<1 \%$ & $16 \%$ & $11 \%$ & $72 \%$ & 3.9 & 22.5 \\
\hline $1996-1997$ & 2.48 & $30 \%$ & $39 \%$ & $9 \%$ & $22 \%$ & 3.4 & 27.5 \\
\hline $1997-1998$ & 1.56 & $<1 \%$ & $3 \%$ & $11 \%$ & $85 \%$ & 0.8 & 23.5 \\
\hline Total & 8.12 & $9 \%$ & $26 \%$ & $11 \%$ & $54 \%$ & 18.7 & 26.5 \\
\hline \multicolumn{8}{|c|}{ Sediment Input Doubled } \\
\hline $1994-1995$ & 6.2 & $13 \%$ & $39 \%$ & $11 \%$ & $37 \%$ & 15.1 & 33.5 \\
\hline $1995-1996$ & 2.0 & $<1 \%$ & $29 \%$ & $11 \%$ & $60 \%$ & 5.8 & 22.5 \\
\hline $1996-1997$ & 5.0 & $50 \%$ & $29 \%$ & $7 \%$ & $14 \%$ & 4.8 & 36.5 \\
\hline $1997-1998$ & 3.2 & $<1 \%$ & $3 \%$ & $11 \%$ & $85 \%$ & 1.4 & 26.5 \\
\hline Total & 16.23 & $20 \%$ & $28 \%$ & $10 \%$ & $42 \%$ & 25.6 & 26.5 \\
\hline \multicolumn{8}{|c|}{ Sediment Input Halved } \\
\hline $1994-1995$ & 1.6 & $<1 \%$ & $9 \%$ & $11 \%$ & $79 \%$ & 4.0 & 23.5 \\
\hline $1995-1996$ & 0.5 & $<1 \%$ & $12 \%$ & $11 \%$ & $77 \%$ & 0.3 & 27.5 \\
\hline $1996-1997$ & 1.3 & $11 \%$ & $45 \%$ & $11 \%$ & $33 \%$ & 2.4 & 27.5 \\
\hline $1997-1998$ & 0.8 & $<1 \%$ & $3 \%$ & $11 \%$ & $86 \%$ & 0.4 & 23.5 \\
\hline Total & 4.06 & $4 \%$ & $19 \%$ & $11 \%$ & $66 \%$ & 7.1 & 23.5 \\
\hline \multicolumn{8}{|c|}{ Uniform Along-Shelf Sediment Distribution } \\
\hline $1994-95$ & 3.12 & $<1 \%$ & $38 \%$ & $9 \%$ & $53 \%$ & 17.9 & 33.5 \\
\hline $1995-96$ & 0.95 & $<1 \%$ & $30 \%$ & $9 \%$ & $63 \%$ & 5.5 & 33.5 \\
\hline $1996-97$ & 2.48 & $20 \%$ & $52 \%$ & $8 \%$ & $20 \%$ & 6.8 & 43.5 \\
\hline $1997-98$ & 1.56 & $<1 \%$ & $4 \%$ & $9 \%$ & $87 \%$ & 1.1 & 29.5 \\
\hline Total & 8.12 & $6 \%$ & $35 \%$ & $9 \%$ & $50 \%$ & 29.6 & 33.5 \\
\hline \multicolumn{8}{|c|}{ No Along-Shelf Slope } \\
\hline $1994-95$ & 3.12 & $<1 \%$ & $24 \%$ & $11 \%$ & $65 \%$ & 8.7 & 26.5 \\
\hline $1995-96$ & 0.95 & $<1 \%$ & $13 \%$ & $11 \%$ & $76 \%$ & 1.5 & 22.5 \\
\hline $1996-97$ & 2.48 & $32 \%$ & $37 \%$ & $7 \%$ & $23 \%$ & 2.8 & 26.5 \\
\hline $1997-98$ & 1.56 & $<1 \%$ & $3 \%$ & $11 \%$ & $87 \%$ & 0.6 & 26.5 \\
\hline Total & 8.12 & $10 \%$ & $22 \%$ & $10 \%$ & $50 \%$ & 13.5 & 26.5 \\
\hline
\end{tabular}

deposition. Figure 5 shows the time series of predicted deposition at $70 \mathrm{~m}$ on the S-transect $(\mathrm{S}-70)$ for the four flood seasons. Although the January 1997 flood was larger than the January 1995 flood, greater midshelf deposition was predicted in association with the January 1995 flood. Over $5 \mathrm{~cm}$ of deposition was predicted at S-70 following the January 1995 flood (beginning on model day 5), while the larger January 1997 flood (beginning on model day 30) resulted in less than $2 \mathrm{~cm}$ of deposition at S-70. This is less than the predicted deposition associated with the much smaller March 1995 flood (beginning on model day 66). Greater wave energy will lead to greater gravity-driven deposition only if sufficient sediment is delivered to critically stratify the wave boundary layer. In the absence of critical stratification, higher wave energy may erode deposited sediment reducing the overall deposition. A comparison of the predicted deposition for 1995-1996 and 1997-1998 illustrates the important relationship between sediment supply and wave energy. The observed wave energy during the 1997-1998 flood season was the greatest of the four winters to which the model was applied (Figure 3). However, the predicted deposition was not largest. Apparently, sufficient sediment was not delivered to critically stratify the boundary layer for significant periods of time. Even though sediment input was roughly $60 \%$ greater in $1997-1998$ than 1995-1996, greater deposition is predicted in 1995-1996. The energetic waves and modest riverine sediment input not only prevented extended periods of critical stratification of the wave boundary layer, but also resulted in significant erosion of sediment at midshelf depths.

[23] Figure 6a shows the total predicted midshelf deposition for the four modeled flood seasons. Despite significantly larger sediment input nearest the river mouth (Figure 2), maximum midshelf deposition was predicted to occur roughly 5 to $30 \mathrm{~km}$ north of the river mouth during all four flood seasons. Minimal midshelf deposition was predicted in the region directly offshore from the river mouth despite this region having the highest inshore sediment input. This is consistent with the analytic results of Scully et al. [2002], which suggest that concave downward bathymetry (increasing off-shelf slope) associated with Eel River subaqueous delta prevents significant midshelf gravity-driven deposition in this region. The midshelf region north of the subaqueous delta, where greatest deposition was predicted and observed, has constant and even decreasing off-shelf slope that favors gravity-driven flux convergence. Further north, predicted deposition begins to diminish with no predicted deposition extending further than $45 \mathrm{~km}$ north of the river mouth. The predicted northern limit of flood deposition is also consistent with core observations [Wheatcroft et al., 1997; Borgeld et al., 1999; Drake, 1999; Sommerfield and Nittrouer, 1999; Wheatcroft and Borgeld, 2000]. The decrease of deposition in this region appears to be the result of diminishing sediment delivery by the Eel River plume. Presumably, sufficient 

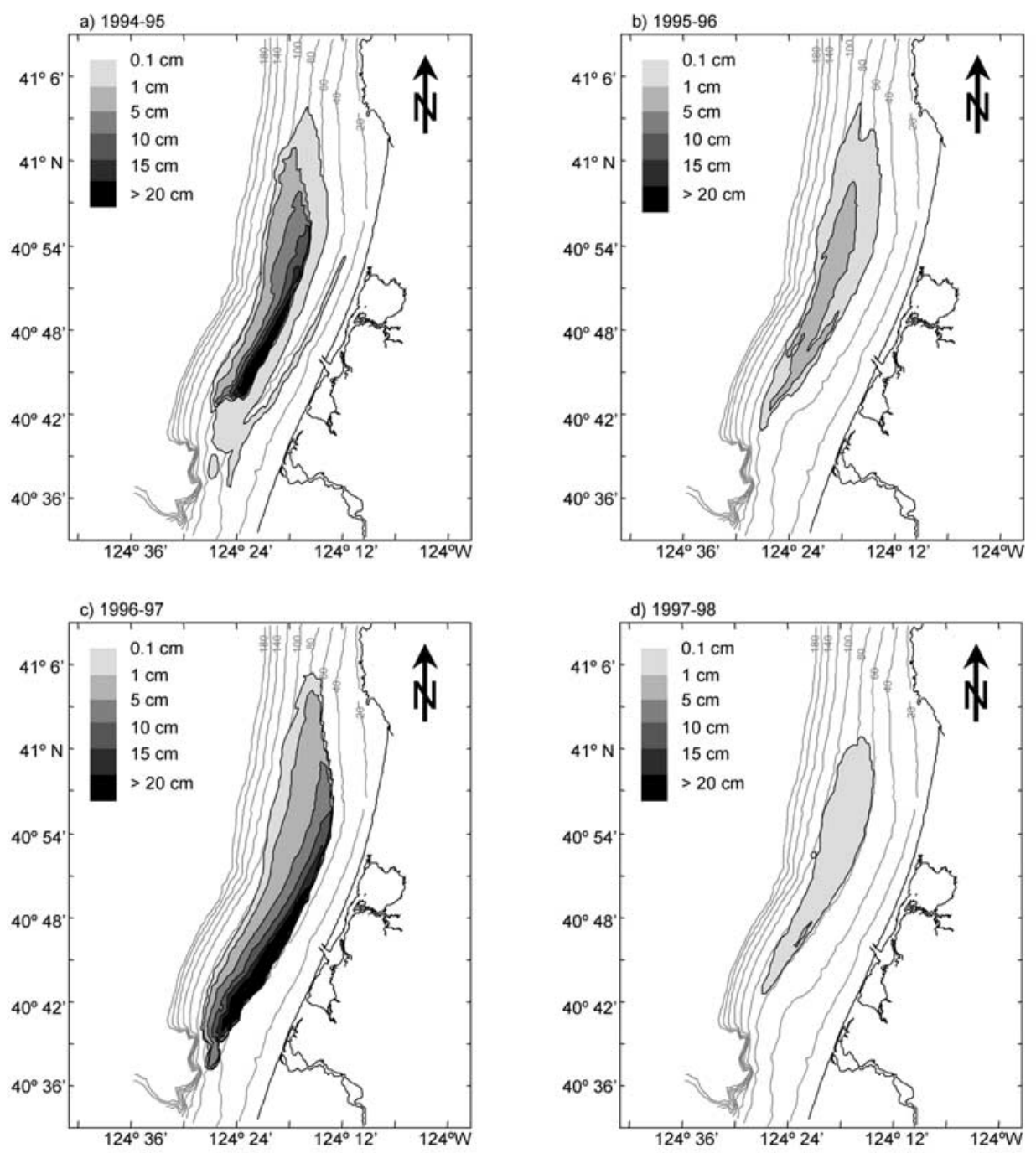

Figure 4. Predicted gravity-driven deposition for (a) 1994-1995, (b) 1995-1996, (c) 1996-1997, and (d) 1997-1998. Deposition was calculated assuming a porosity of 0.75 .

sediment was not delivered to critical stratify the wave boundary layer, preventing gravity-driven sediment transport and deposition.

\subsection{Inner-Shelf Deposition}

[24] Following the large flood of 1996-1997, significant deposition was predicted on the inner shelf. Predicted innershelf deposition was highest in the region near the river mouth where the largest along-shelf input of sediment was supplied (Figure 6b). During 1996-1997, approximately $30 \%$ of the fine sediment discharged by the Eel River was predicted to be deposited inshore of the $50-\mathrm{m}$ isobath. In contrast, no significant deposition was predicted to remain inshore of the 50-m isobath during 1994-1995, 1995-1996 or 1997-1998. The January 1997 flood was the largest flood event that was modeled (with presumably the greatest sediment input), but the associated wave energy was relatively low. As a result, significantly greater sediment was supplied by the river plume than could be transported offshore by gravity-driven processes. The more energetic waves associated with the large floods of 1995 allowed greater transport

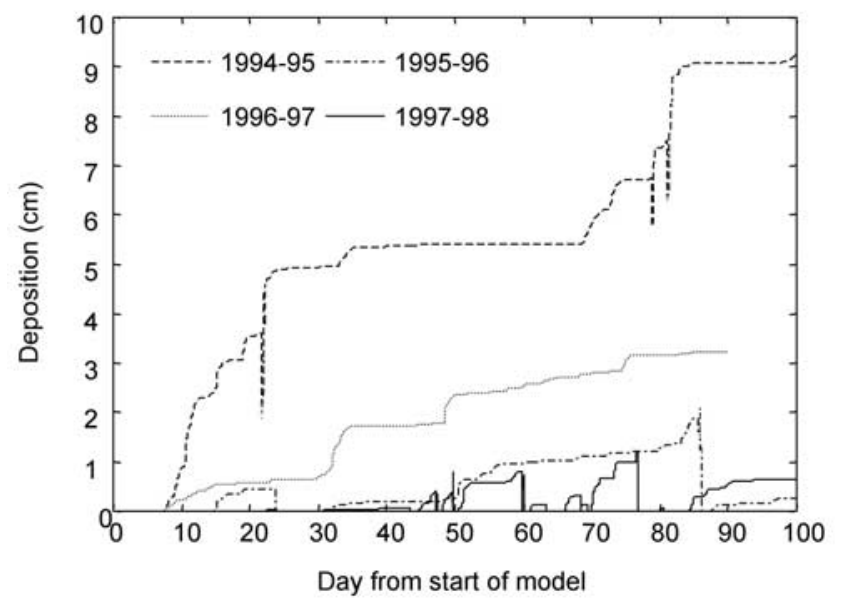

Figure 5. Time series of predicted deposition at S-70 assuming porosity of 0.75 for four flood seasons. 
a) Total mid-shelf gravity-driven deposition ( $>50 \mathrm{~m})$
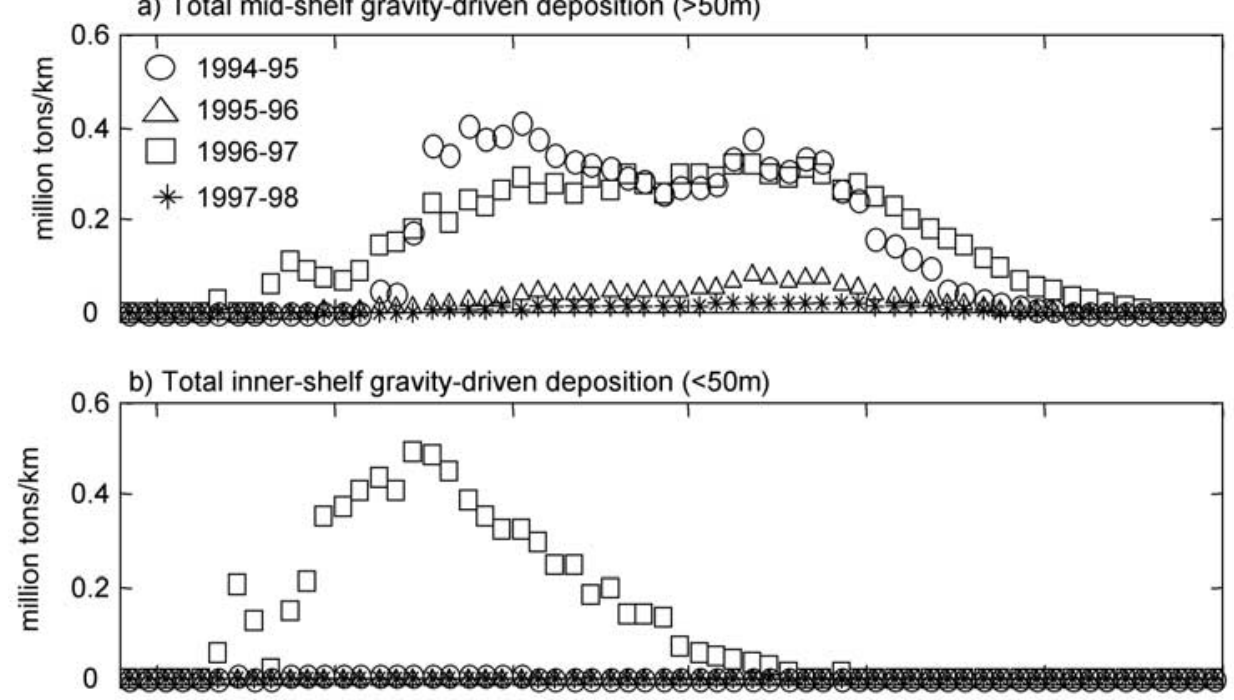

c) Total off-shelf gravity-driven flux

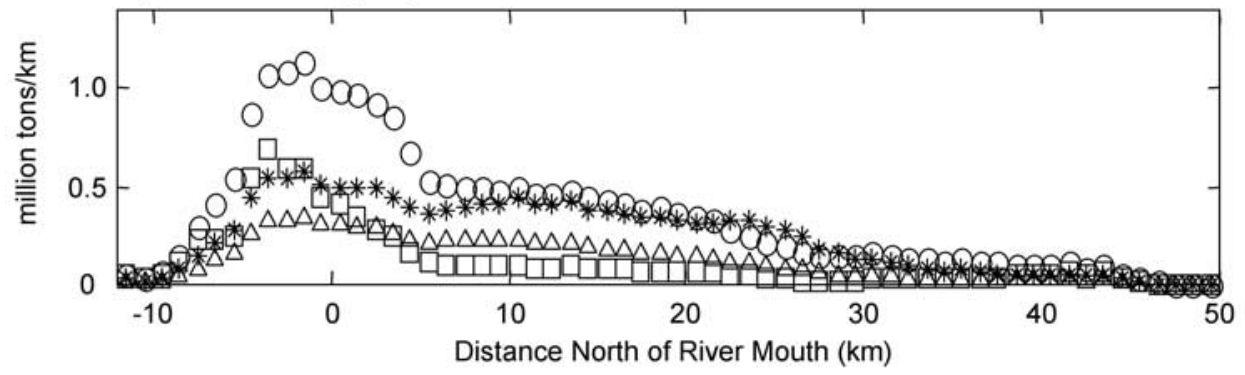

Figure 6. Along-shelf distribution of cumulative (a) midshelf gravity-driven deposition, (b) inner-shelf deposition, and (c) off-shelf gravity-driven flux predicted by the model for the four flood seasons.

of sediment offshore resulting in greater midshelf deposition. Significant inner-shelf deposition was predicted during the large floods in 1995, however subsequent wave events resuspended this sediment and the majority was transported farther offshore.

[25] Although observations have not documented widespread deposition of fine sediment on the inner shelf, cores collected from the inner shelf reveal that fine-grained sediment layers are preserved locally within the inner-shelf sands (Crockett and Nittrouer, submitted manuscript, 2002). While energetic waves and currents may subsequently disperse much of the predicted inner-shelf deposition, our results suggest that the potential for preservation exists, with roughly $9 \%$ of the sediment discharge over the four flood seasons predicted to remain on the inner shelf (Table 1). Additionally, there is direct observational evidence for rapid deposition of fine sediment on the inner shelf following floods of the Eel River. Traykovski et al. [2000] report that a bottom-mounted acoustic Doppler current profiler (ADCP) deployed at $20 \mathrm{~m}$ on the K-transect was buried under an estimated $1 \mathrm{~m}$ of mud soon after a flood early in 1998. Although such extreme deposition was not predicted by our model, these observations suggest that the rapid delivery of sediment from the Eel River plume may have been capable of overwhelming the capacity of the boundary layer resulting in the observed inshore deposition on the K-transect.
[26] While our results suggest that gravity-driven processes alone are not capable of removing all of the sediment delivered to the inner shelf immediately following large floods, the processes governing the delivery and potential preservation of fine sediment on the inner shelf represents a gap in the understanding of this system. The surf zone, which during large storms may comprise a significant percentage of the inner shelf region, may play a key role in sediment delivery and preservation. Our model does not account for the complex interactions that occur within the surf zone. Preservation of fine material on an energetic inner-shelf such as the Eel River is probably unlikely unless it is rapidly covered by coarser grained material. Again, because our model does not account for sand, such processes cannot be addressed here. Lastly, the model does not account for consolidation, which may play a key role in the preservation of fine sediment on the inner shelf.

\subsection{Off-Shelf and Canyon Delivery}

[27] The model predicts that significant sediment may be capable of leaving the shelf as gravity-driven flows that enter Eel Canyon or traverse the shelf to the shelf break. Wright et al. [2001] found that the slope of the continental shelf was generally too gentle to allow significant gravitydriven transport in the absence of an external source of turbulence. On an energetic margin such as that off northern California, waves play a key role in allowing gravity-driven 


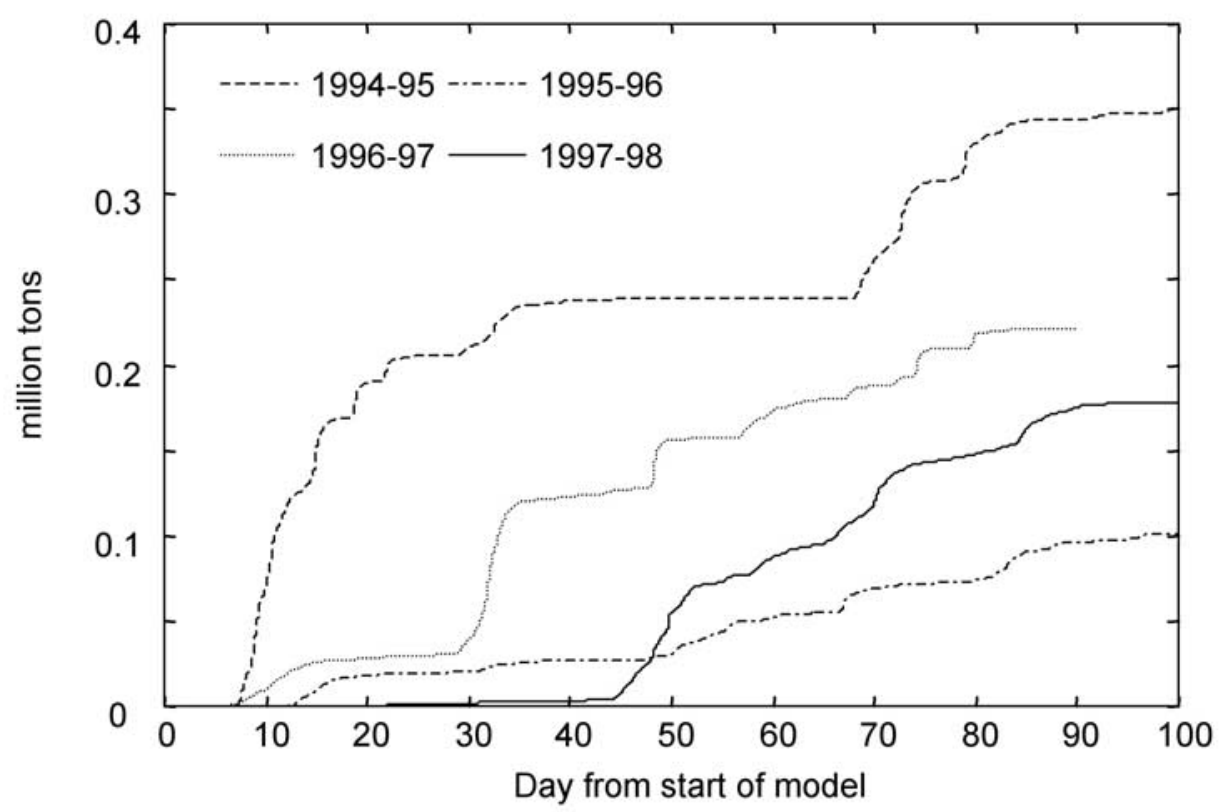

Figure 7. Time series of cumulative gravity-driven sediment flux into Eel Canyon for four flood seasons.

flows to propagate across-shelf [Traykovski et al., 2000]. It follows that greater wave energy allows greater gravitydriven flux, increasing the likelihood that sediment may leave the shelf as a gravity flow. The 1996-1997 season had the lowest amount of sediment predicted to leave the shelf despite having the second highest total sediment input (Table 1). This is a direct consequence of the relatively low wave energy that occurred during this year. As a result, 9\% of the fine sediment discharge was predicted to enter Eel Canyon with $22 \%$ escaping past the shelf break. In contrast, the more energetic waves in the other three winters allowed significantly more sediment to escape the shelf. Roughly $70 \%$ and $83 \%$ of the sediment discharge was predicted to leave the shelf during 1994-1995 and 1995-1996, respectively, and nearly all of the sediment input was predicted to leave the shelf in 1997-1998. Over all 4 years, $66 \%$ of the fine sediment discharge was predicted to leave the shelf. These results may overestimate off-shelf flux because the consolidation of fine sediment was not included in the model. In reality, rapid consolidation of fine sediment could have limited sediment resuspension following flood events, reducing the actual off-shelf flux. However, Scully [2001] did include a simple formulation for consolidation in their results and still predicted over $50 \%$ of sediment input to leave the shelf as gravity flows for all 4 years when consolidation was assumed to occur in 1 week.

[28] Recent investigations reveal that flood sediment is entering Eel Canyon [Mullenbach and Nittrouer, 2000]. Cores collected from the head of the canyon in January 1998 before any significant river discharge for the season reveal little ${ }^{7} \mathrm{Be}$ evidence for river derived sediment. However, later in March following a period of elevated river discharge and energetic waves, cores revealed a 30 -fold increase of ${ }^{7} \mathrm{Be}$ inventories, with elevated ${ }^{7} \mathrm{Be}$ extending down nearly $10 \mathrm{~cm}$ [Mullenbach and Nittrouer, 2000]. Model results indicate that there was significant flux of river-derived sediment by gravity flows (about $11 \%$ of the total) that can account for the observations collected at the head of Eel Canyon. Figure 7 shows the predicted time series of cumulative flux into Eel Canyon for the 4 modeled years. Prior to day 40 of the model run (which corresponds to January 10, 1998), no sediment flux into the canyon was predicted. However, nearly $2.0 \times 10^{5} \mathrm{t}$ of sediment was predicted to enter the canyon due to gravity-driven transport during the flood events of January and February of 1998.

[29] The results of Scully et al. [2002] also provide evidence that the bathymetry associated with the Eel River subaqueous delta inhibits deposition and favors gravitydriven sediment bypassing to the slope near the river mouth. While midshelf deposition predicted off the river mouth is significantly less than that predicted further to the north, the flux of sediment off-shelf is highest near the mouth (Figure 6c). While the inshore sediment input is greatest in this region, the lack of deposition supports the concept of bathymetry controlled gravity-driven bypassing. Thus, the model results suggest that the majority of the fine-grained sediment discharged from the Eel River may leave the shelf as gravity-driven flows.

\section{Model Sensitivity}

[30] The ability of the model to reproduce the large-scale patterns of deposition that are consistent with observations collected from the margin provides some confidence that our approach is sensible. However, in implementing the model, several important processes were either simplified or neglected to better highlight the dominant processes. Model runs were conducted to examine how these simplifications and assumptions affected the results. While the key results obtained from our sensitivity analysis are presented below, model runs that included the roles of consolidation, alongshelf currents, and changes to the critical resuspension 


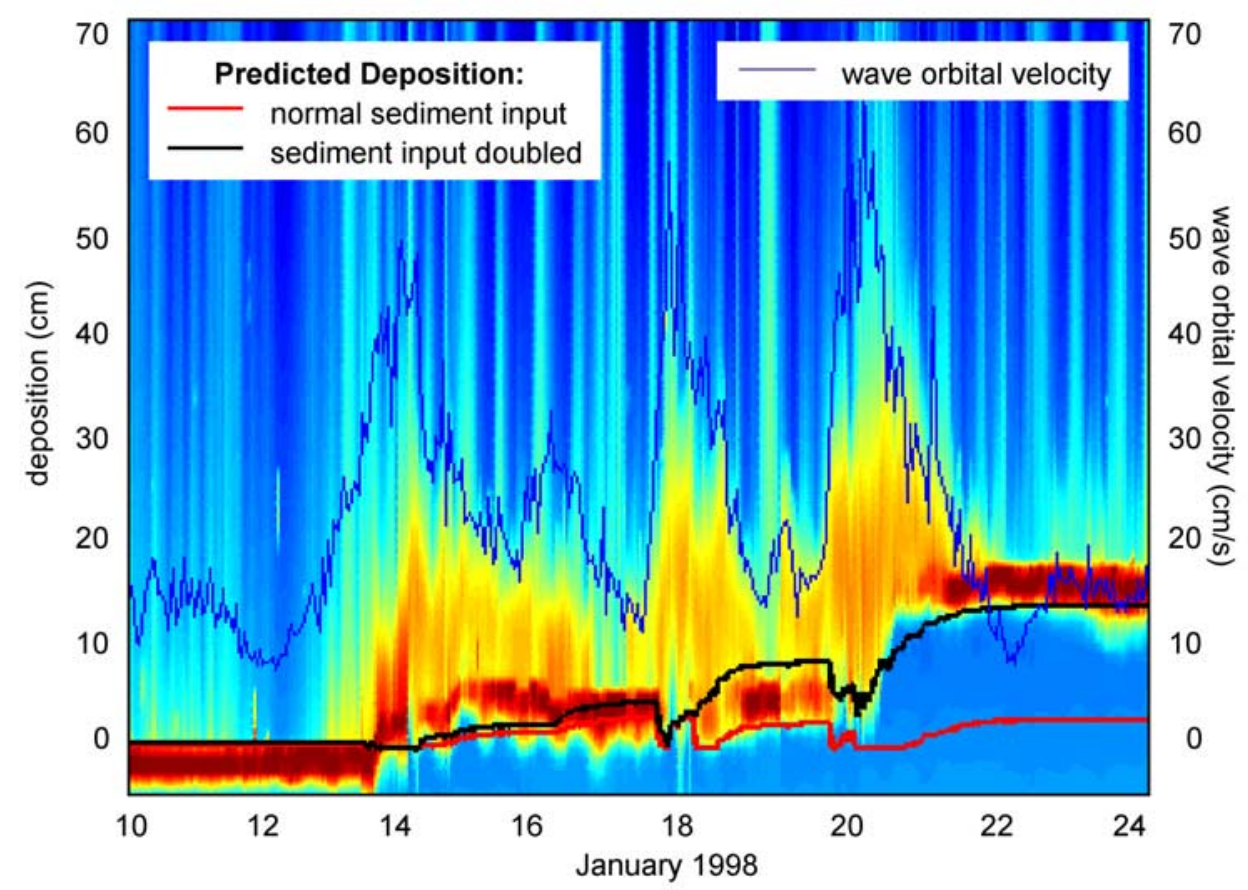

Figure 8. ABS image of bed elevation change and predicted deposition at K-60 in 1997-1998 assuming normal sediment delivery (red line) and a two-fold increase in sediment delivery (black line), assuming porosity of 0.90 . ABS data are from Traykovski et al. [2000]. Wave orbital velocities calculated from NDBC buoy 46022 are shown in blue.

threshold have been omitted here for brevity and because midshelf deposition was found to be relatively less sensitive to these parameters (see Scully [2001] for details).

\subsection{Delivery of River Sediment}

[31] The inshore delivery of fine sediment from the Eel River plays a key role influencing where and when gravitydriven processes occur. However, analytic modeling results suggest that as long as sufficient sediment is delivered to critically stratify the wave boundary layer, the large-scale pattern of deposition will be controlled mainly by the waves and bathymetry [Scully et al., 2002]. The results of the base model runs presented above provide additional support for this idea. Greater sediment deposition is predicted well north of the river mouth despite greatest sediment input close to the river mouth. To examine the impact of sediment delivery on model results, the model was run changing (1) the amount and (2) the along-shelf distribution of sediment input (Table 1).

\subsubsection{Amount of Sediment Delivery}

[32] The amount of sediment delivered to the inner shelf by the river plume is a poorly constrained input into our model. Uncertainty associated with the rating curve, as well as the possibility that sediment leaves the model domain without ever settling from the plume, could potentially influence the accuracy of the model results. Accordingly, model runs were conducted in which the amount of sediment supplied to the inner-shelf by the river was varied. The impact of changing the amount of sediment delivered into the model varied significantly from year to year (Table 1). This is mainly the result of the relationship between sediment supply and wave energy. This can be illustrated most effectively by examining the changes in predicted deposition in 1996-1997 versus 1997-1998 in response to doubling and halving the supply of sediment input into the model.

[33] In the 1996-1997 base model run, the large input of sediment and low wave energy allowed the boundary layer at the midshelf to remain critically stratified for significant periods of time. Because for much of the time the midshelf boundary layer was already carrying its maximum capacity, an increase in available sediment did not result in a proportional increase in midshelf deposition. Total midshelf deposition was predicted to increase by only $49 \%$ (Table 1 ), with the maximum predicted thickness for the 70-m depth increasing only $25 \%$. The majority of the additional sediment remained on the inner shelf, where the predicted deposition increased by $230 \%$. The capacity of the wave boundary layer controlled by relatively low wave energy could not transport significantly more sediment to the midshelf.

[34] In contrast, doubling the sediment input for 19971998 had a much larger impact on the predicted midshelf deposition. Midshelf deposition increased by $100 \%$ and the maximum predicted deposition along the $70-\mathrm{m}$ isobath increased by $75 \%$ (Table 1). Interestingly, the increased sediment input resulted in a much more reasonable agreement between the predicted and observed deposition at K60 (Figure 8). (In Figure 8, deposition thickness was calculated assuming a porosity of 0.90 , consistent with the initial water content observed in flood layers from the Eel margin by Drake [1999]. However, after consolidation and compaction the overall thickness preserved on the shelf would likely be less as porosity decreases.) Assuming the 
increased sediment delivery, the model predicted the wave boundary layer at K-60 to remain critically stratified during the large wave event beginning on January 20, 1998, when the most significant deposition was observed by Traykovski et al. [2000]. Without increasing the sediment input, insufficient sediment was available to maintain critical stratification during this wave event and the model predicted erosion. While model results at K-60 agree more favorably with tripod observations when the sediment input is doubled, significantly greater deposition also was predicted over much of the midshelf for this case. Given the lack of evidence of flood layers observed in cores associated with this flood season, it is more likely that localized processes related to the delivery of sediment from the river plume may have resulted in higher sediment delivery in the immediate vicinity of the K-transect.

[35] The results presented above assume that all of the sediment from the Eel River was available for transport by gravity-driven processes. However, observations and modeling of sediment delivery from the Eel plume indicate that a fraction of unflocculated sediment may remain in the plume and be transported beyond our model domain [Harris et al., 1999; Hill et al., 2000]. To account for the possibility that a significant amount of sediment is widely dispersed and not available for transport by gravity-driven flows, the model was run reducing the sediment input by $50 \%$. With the exception of 1997-1998, decreased sediment input did not result in a proportional decrease in the percent of total sediment deposited on the midshelf. In both 1994-1995 and 1995-1996, decreased sediment input resulted in proportionally less midshelf deposition. Lower sediment input combined with the intense wave energy led to less critical stratification and greater erosion, lowering midshelf deposition and resulting in proportionally more off-shelf flux. Conversely, in 1996-1997 decreased sediment input resulted in proportionally more midshelf deposition because inner-shelf deposition decreased markedly. Even with the significant reduction in sediment input, long periods of critical stratification still occurred over the midshelf in 1996-1997, and midshelf deposition was not decreased as much as in other years. For both 1994-1995 and 19961997, when significant midshelf deposition was observed in cores, the model underpredicted both the local thickness and total mass of deposition when the sediment input into the model was significantly reduced. These results suggest that either most of the sediment discharge from the river is indeed available for gravity-driven transport or, if much of the sediment discharge is unavailable, then our estimates based on the rating curve significantly underestimate the delivery of sediment. Either way, it seems to indicate that large amounts of sediment must be rapidly delivered to the adjacent coastal ocean in order for gravity-driven processes to result in widespread midshelf deposition.

[36] The extremely high sediment yields and rapid response of the Eel River's mountainous basin quickly deliver large quantities of fine sediment during ocean storm conditions, allowing gravity-driven transport and deposition to dominate the transport of fine sediment. Other systems along the west coast of the United States probably do not deliver sufficient quantities of fine sediment to initiate widespread gravity-driven transport with regularity. However, worldwide there are a number of river systems that discharge a sufficient sediment load into an energetic coastal ocean where gravity-driven processes may play a key role in the transport and deposition of sediment. The continental shelves off the Waipaoa River in New Zealand [Foster and Carter, 1997], the Gulf of Cadiz in Spain [Lopez-Galindo et al., 1999], and the Bengal Shelf [Kuehl et al., 1989] are all actively accumulating and/or bypassing mud under moderate to high energy wave conditions. All of these environments are subject to high sediment input and high wave conditions associated with storms, during which wave-supported gravity-driven flows are likely to play a role in down-slope sediment transport.

\subsubsection{Along-Shelf Distribution of Sediment}

[37] Model results obtained by using a uniform alongshelf distribution of sediment highlight several important features of the Eel River depositional system. For all 4 years, not only was gravity-driven midshelf deposition still favored well north of the river mouth, but the region of maximum deposition also was shifted to the north. Additionally, the overall maximum predicted thickness at $70 \mathrm{~m}$ increased significantly (Table 1). Scully et al. [2002] suggested that the bathymetry of the midshelf favored increased gravity-driven deposition moving north away from the river mouth if one assumed an unlimited along-shelf delivery of sediment. Decreasing midshelf deposition should begin where the northerly delivery of river sediment can no longer exceed the capacity of the wave boundary layer for periods long enough to allow significant critically stratified gravitydriven transport to occur. Our model runs using a uniform along-shelf distribution of sediment did effectively move the predicted region of maximum midshelf deposition to the north. Contrary to the analytical predictions of Scully et al. [2002], however, greatest deposition was not observed at the northern limit of the model domain. This decrease in predicted deposition toward the northern limit of the model domain while using a uniform distribution of sediment input suggests that factors not related to sediment delivery also contribute to decreased deposition along the northern region of the model. Potential explanations for this will be addressed in the next section discussing the influence of the along-shelf slope.

\subsection{Along-Shelf Slope}

[38] Near the northern edge of the model, the coastline trends slightly more to the north-northwest approaching Trinidad Head. With the depth contours roughly paralleling the coastline, the bed slope in this region has a stronger southerly component. To assess the importance of the alongshelf component of the bed slope, the model was run using only the across-shelf component of the bed slope, ignoring all transport induced by the along-shelf slope. These model runs used the exponentially decaying along-shelf distribution of sediment depicted in Figure 2. As seen in Figure 9, the along-shelf component of the slope clearly increased the predicted deposition in the region from 5 to $35 \mathrm{~km}$ north of the river mouth, while decreasing deposition at the northern and southern ends of the model domain. Maximum deposition from all 4 years along the $70-\mathrm{m}$ isobath was increased by $39 \%$. This increase in deposition comes at the expense of deposition along the northern and southern regions of the model. So, not only is the across-shelf bathymetry associated with the Eel River subaqueous delta unfavorable to gravity- 


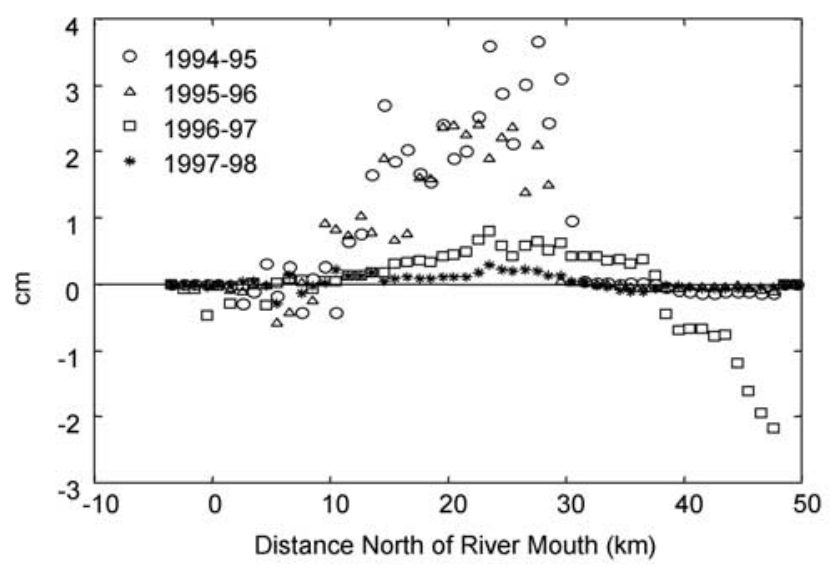

Figure 9. Change in predicted deposition along 70-m isobath due to including effect of along-shelf slope for 1994-1995 (circles), 1995-1996 (triangles), 1996-1997 (squares), and 1997-1998 (asterisks). The predicted deposition along the 70-m isobath without including the influence of the along-shelf slope was subtracted from the predicted deposition including the influence of the alongshelf slope.

driven deposition, but the northerly directed slopes associated with delta appear to preferentially steer gravity-driven transport away from this region. The along-shelf slope tends to enhance gravity-driven deposition near the observed region of the flood depo-center. The southerly directed slopes near Eel Canyon do not appear to divert significant sediment into Eel Canyon. In fact, the flux into Eel Canyon remained relatively unchanged. Along the northern portion of the model, the southerly-directed slopes associated with Trinidad Head divert gravity-driven transport to the south, explaining why deposition is not predicted to continually increase to the north.

\section{Conclusions}

[39] The numerical model presented in this paper is intended to simulate large-scale gravity-driven deposition of the fine sediment derived from floods of the Eel River on the adjacent continental shelf. It builds upon the previous work of Scully et al. [2002] by incorporating realistic and time-varying sediment supply and 2-D shelf bathymetry. The model demonstrates an ability to reproduce both the magnitude and location of observed flood deposition on the midshelf. The thickest midshelf deposits are predicted to coincide with large floods that have the highest associated wave energy. The model predicted that roughly $25 \%$ of the total input of fine sediment was deposited on the midshelf. Significant inner-shelf deposition (depth $<50 \mathrm{~m}$ ) of mud was predicted following large floods associated with relatively low wave energy. For all 4 years, inner shelf deposition accounted for roughly $9 \%$ of the total fine sediment input. When the wave energy is high or floods are small, a significant amount of sediment input was predicted to escape across the shelf or enter Eel Canyon as gravitydriven flows (roughly $65 \%$ of the total input).

[40] With the exception of extremely large floods, sensitivity analysis indicates that the input of sediment into the model is also an important parameter. A 50\% reduction in sediment input caused the model to underpredict observed midshelf deposition. This suggests that if our estimates based on the rating curve are accurate, most of the fine sediment discharged from the river must be available for gravity-driven transport during moderate to large floods in order to produce the observed flood deposits. This also suggests that on margins with bathymetry and accumulation rates comparable to the Eel shelf, but adjacent to rivers with a significantly smaller sediment load, gravity-driven processes may not play a similarly dominant role in the transport and deposition of sediment on the midshelf during floods. Doubling the sediment supply did not significantly increase midshelf deposition during very large floods, indicating that gravity-driven deposition does place an upper limit on the amount of sediment that can be placed on the midshelf during large events.

[41] Bathymetric controls caused model results to be relatively insensitive to the along-shelf distribution of sediment. Greatest midshelf deposition was consistently predicted to occur in the region $5-30 \mathrm{~km}$ north of the river mouth, despite greater sediment input near the river mouth. This is the net result of two aspects of the shelf bathymetry: (1) Relatively constant to slightly concave upward acrossshelf bathymetric profiles favor greater across-shelf gravitydriven flux convergence, and (2) northerly directed slopes associated with the Eel River subaqueous delta combined with southerly directed slopes approaching Trinidad Head favor along-shelf flux convergence. However, increased sediment delivery to the inshore region near the river mouth did shift the location of the predicted depo-center slightly to the south from the bathymetrically favored region.

[42] Acknowledgments. The analyses reported in this paper were supported by the Office of Naval Research, Marine Geology and Geophysics (grant N00014-95-1-0391), as a component of the STRATAFORM Program. This work builds directly on the previous work by the numerous investigators involved in the STRATAFORM Program. We would like to thank P. Traykovski who provided useful comments on the original manuscript as well as data with which the model was compared. This paper benefited greatly from helpful suggestions by two anonymous reviewers. This is contribution 2508 from the Virginia Institute of Marine Science, College of William and Mary.

\section{References}

Borgeld, J. C., J. E. Hughes Clark, J. A. Goff, L. A. Mayer, and J. A. Curtis, Acoustic backscatter of the 1995 flood deposit on the Eel shelf, Mar. Geol., 197, 197-210, 1999.

Brown, W. M., and J. R. Ritter, Sediment transport and turbidity in the Eel River basin, California, U.S. Geol. Surv. Water Supply Pap., 1986, 70 pp., 1971.

Drake, D. A., Temporal and spatial variability of the sediment grain-size distribution on the Eel shelf: The flood layer of 1995, Mar. Geol., 154, $169-182,1999$.

Drake, D. E., R. A. Wheatcroft, J. C. Borgeld, and A. S. Ogston, The formation and fate of flood and storm deposits on the Eel Shelf, Eos. Trans. $A G U, 81(48)$, Fall Meet. Suppl., OS61A-10, 2000.

Foster, G., and L. Carter, Mud sedimentation on the continental shelf at an accretionary margin: Poverty Bay, New Zealand, N. Z. J. Geol. Geophys., 40, 157-173, 1997

Geyer, W. R., P. Hill, T. Milligan, and P. Traykovski, The structure of the Eel River plume during floods, Cont. Shelf Res., 20, 2067-2093, 2000.

Harris, C. K., W. R. Geyer, and R. P. Signell, Eos. Trans. AGU, 80(49), Ocean Sci. Meet. Suppl., OS42K-06, 1999.

Hill, P. S., T. G. Milligan, and W. R. Geyer, Controls on effective settling velocity of suspended sediment in the Eel River flood plume, Cont. Shelf Res., 20, 2095-2112, 2000

Komar, P. D., Computer simulation of turbidity current flow and the study of deep-sea channels and fan sedimentation, in The Sea, vol. 6, Marine 
Modeling, edited by E. D. Goldberg et al., pp. 603-621, Wiley-Intersci., New York, 1977.

Kuehl, S. A., T. M. Hairu, and W. S. Moore, Shelf sedimentation off the Ganges-Brahmaputra river system: Evidence for sediment bypassing of the Bengal fan, Geology, 17, 1132-1135, 1989.

Kundu, P. K., Self-similarity in stress-driven entrainment experiments, J. Geophys. Res., 86, 1979-1988, 1981.

Lopez-Galindo, A., J. Rodero, and A. Maldonado, Surface facies and sediment dispersal patterns: Southeastern Gulf of Cadiz, Spanish continental margin, Mar. Geol., 155, 83-98, 1999.

Mulder, T., and J. P. M. Syvitski, Turbidity currents generated at river mouths during exceptional discharges to the world ocean, J. Geol., 103, 285-299, 1995.

Mulder, T., J. P. M. Syvitski, and K. I. Skene, Modeling of erosion and deposition by turbidity currents generated at river mouths, J. Sediment. Res., 68, 124-137, 1998.

Mullenbach, B. L., and C. A. Nittrouer, Rapid deposition of fluvial sediment in the Eel Canyon, northern California, Cont. Shelf Res., 20, $2191-$ 2212,2000

Nittrouer, C. A., STRATAFORM: Overview of its design and synthesis of its results, Mar. Geol., 154, 3-12, 1999.

Ogston, A. S., D. A. Cacchione, R. W. Sternberg, and G. C. Kineke, Observations of storm and river flood-driven sediment transport on the northern California continental shelf, Cont. Shelf Res., 20, 2141-2162, 2000.

Parker, G., Y. Fukushima, and H. M. Pantin, Self-accelerating turbidity currents, J. Fluid Mech., 171, 145-181, 1986.

Price, J. F., On the scaling of stress-driven entrainment experiments, J. Fluid Mech., 90, 509-529, 1979.

Scully, M. E., Modeling critically-stratified gravity flows: Application to the Eel River continental shelf, northern California, M.S. thesis, 101 pp., Coll. of William and Mary, Williamsburg, Va., 2001. (Available at http://www.vims.edu/ cfried/publications/reports)

Scully, M. E., C. T. Friedrichs, and L. D. Wright, Application of an analytical model of critically-stratified gravity-driven sediment transport and deposition to observations from the Eel River continental shelf, northern California, Cont. Shelf Res., 22, 1951-1974, 2002.
Sherwood, C. R., B. Butman, D. A. Cacchione, D. E. Drake, T. F. Gross, R. W. Sternberg, P. L. Wiberg, and A. J. Williams, Sediment-transport events on the northern California continental shelf during the 1990-1991 STRESS experiment, Cont. Shelf Res., 14, 1063-1099, 1994.

Sommerfield, C. K., and C. A. Nittrouer, Modern accumulation rates and a sediment budget for the Eel shelf: A flood-dominated depositional environment, Mar. Geol., 154, 227-242, 1999.

Syvitski, J. P., and M. D. Morehead, Estimating river-sediment discharge to the ocean: Application to the Eel margin, northern California, Mar. Geol., 154, 13-28, 1999.

Thompson, R. O. R. Y., A reinterpretation of the entrainment process in some laboratory experiments, Dyn. Atmos. Oceans, 4, 45-55, 1979.

Traykovski, P., W. R. Geyer, J. D. Irish, and J. F. Lynch, The role of waveinduced density-driven fluid mud flows for cross-shelf transport on the Eel River continental shelf, Cont. Shelf Res., 20, 2113-2140, 2000.

Trowbridge, J. H., and G. C. Kineke, Structure and dynamics of fluid muds on the Amazon continental shelf, J. Geophys. Res., 99, 865-874, 1994. Wheatcroft, R. A., and J. C. Borgeld, Oceanic flood deposits on the northern California shelf: Large-scale distribution and small-scale physical properties, Cont. Shelf Res., 20, 2163-2190, 2000.

Wheatcroft, R. A., C. K. Sommerfield, D. E. Drake, J. C. Borgeld, and C. A. Nittrouer, Rapid and widespread dispersal of flood sediment on the northern California margin, Geology, 25, 163-166, 1997.

Wright, L. D., S.-C. Kim, and C. T. Friedrichs, Across-shelf variations in bed roughness, bed stress and sediment transport on the Northern California Shelf, Mar. Geol., 154, 99-115, 1999.

Wright, L. D., C. T. Friedrichs, S.-C. Kim, and M. E. Scully, The effects of ambient currents and waves on the behavior of turbid hyperpycnal plumes on continental shelves, Mar. Geol., 175, 25-45, 2001.

C. T. Friedrichs, M. E. Scully, and L. D. Wright, Virginia Institute of Marine Science, College of William and Mary, Gloucester Point, VA 23062, USA. (cfried@vims.edu; mscully@vims.edu; wright@vims.edu) 